\title{
Association between Knowledge, Perceived Seriousness, Perceived Benefit and Barrier, and Family Support on Adherence to Anti- Retrovirus Therapy in Patients with HIV/AIDS
}

\author{
Sunaryo $^{1)}$, Argyo Demartoto2), Rita Benya Adriyani3) \\ 1)Department of Health, Surakarta \\ 2)Department of Social and Political Sciences, Universitas Sebelas Maret \\ 3) School of Health Polytechnics Surakarta
}

\begin{abstract}
Background: The cumulative of HIV/AIDS cases in Surakarta are 1.212 cases, and 376 of them died in the span of Oktober 2005 until Januari 2014. HIV infections have not found a cure, so it is possible someone with AIDS often experience psychological problems, especially anxiety, depression, which can suppress the immune system, making people more vulnerable against illness and pain. AIDS can not be cured, but the life expectancy of people living with HIV/ AIDS (PLWHA) can be extended with antiretroviral treatment (ART). This treatment can boost immunity so that the quality of life of PLHIV increased.

Subjects and Method: The study was observational analytic research with cross sectional design. The location of research in PHC Manahan Surakarta total of 36 patients with HIV / AIDS who do ARV therapy. The data analysis using logistic regression.

Results: There is a positive correlation was not statistically significant from the knowledge of the drugs with antiretroviral therapy adherence $(\mathrm{OR}=4.03 ; 95 \% \mathrm{CI}=0.22$ to $73.32 ; \mathrm{p}=0.347)$. There is a positive correlation was statistically significant on the perception of the seriousness of the disease with antiretroviral therapy adherence $(\mathrm{OR}=26.70 ; 95 \% \mathrm{CI}=1.30$ to $550.51 ; \mathrm{p}=0.033)$. There is a positive relationship and statistically significant on the perception of the benefits and barriers to compliance with antiretroviral therapy $(\mathrm{OR}=17.73 ; 95 \% \mathrm{CI}=1.12$ to $279.59 ; \mathrm{p}=0.041)$. There is a positive correlation was statistically significant from family support with antiretroviral therapy adherence $(\mathrm{OR}=28.89 ; 95 \% \mathrm{CI}=1.24$ to $647.71 ; \mathrm{p}=0.036)$.

Conclusion: The perception of the seriousness of the disease is the most variable bergubungan with antiretroviral therapy adherence $(\mathrm{p}=0.033)$.
\end{abstract}

Keywords: knowledge about ARV, seriousness of the disease, barriers and family support, adherence ARV therapy

Correspondence:

Sunaryo. Department of Health, Surakarta. Email: Sunaryomanahan@gmail.com.

\section{BACKGROUND}

Data from the World Health Organization (WHO) shows that 35 million people in the world at the end of 2013 were affected by Human Immunodeficiency Virus/ Acquired Immunodeficiency Syndrome (HIV/ AIDS), in the same year 2.1 million people were infected and 1.5 million died because of HIV / AIDS (WHO, 2015).

Data from the Directorate General of Disease Control and Environmental Health of the Ministry of Health of the Republic of Indonesia in July to September 2014 quarter reported an additional 7,335 HIV cases and 176 AIDS cases (Directorate General of PP \& PL of the Indonesian Ministry of Health, 2014).

In 2014, in Central Java, there were 9,032 HIV cases and 3,767 AIDS cases. AIDS Commission (KPA) noted that cases of people with HIV / AIDS (PLWHA) in Solo reached 1,212 people. Of these, 376 of 
them died. This finding refers to KPA Solo data collection in mid-October 2005 to January 2014 (KPAD Solo, 2014).

There are many risk factors of the transmission of HIV / AIDS, but the most important ones are the factors of parenteral sexual behavior and a history of sexually transmitted infections previously suffered. Risky sexual behavior is the main factor associated with HIV / AIDS transmission. Many sex partners who do not use condoms in carrying out sexual activities at risk are the main risk factors for HIV/ AIDS transmission. In fact, the use of condoms is a way to prevent effective HIV/ AIDS transmission. Anal sex is also a factor in sexual behavior that facilitates transmission of HIV / AIDS. The use of narcotics and illegal drugs (injections) or injection or Injecting Drug Users (IDUs) are the main factors in the transmission of HIV / AIDS, including in Indonesia (Laksana and Lestari, 2010).

Physiologically, HIV attacks the immune system of the patients and if added with prolonged spiritual psychosocial stress, it will accelerate the occurrence of AIDS, even increasing mortality. AIDS cannot be cured, but the life expectancy of people living with HIV / AIDS (ODHA) can be extended by the treatment of antiretroviral drugs. This treatment can improve the immune system of people living with HIV so that their quality of life increases (Rachmawati, 2013).

The use of antiretrovirals in patients with positive HIV testing is an effort to prolong the life expectancy of people with HIV-AIDS, known as PLWHA (people with HIV AIDS). ARVs work against infections by slowing down the reproduction of HIV in the body. Generally, effective ARVs are used in combination, not to heal, but to prolong the lives of PLWHA, make them healthier, and be more productive by reducing viraemia and increasing the number of $\mathrm{CD}_{4}+5$ cells. In addition to the combination form, the use of ARVs must be continuous, so very susceptible to noncompliance that can foster HIV resistance (Yuniar, et al, 2013).

The use of antiretroviral drugs requires a high level of compliance to get the success of therapy and prevent resistance. To get a response to the suppression of the virus amounting to $85 \%$, compliance with drug use is $90-95 \%$, so the drug cannot function or fail (Martoni, 2012).

Non-compliance with ARVs is not only a medical problem, but also influenced by the socio-cultural aspects of the local community. Social perspectives can help understand that health and health services are not merely medical issues, but are also social issues. When social approaches and medical approaches are carried out together, the emphasis is not only on the social process of occurrence of a disease and illness, but also on the interventions within social and cultural structures to prevent or even treat the disease (Yuniar et al, 2013).

\section{SUBJECTS AND METHOD}

This study is an observational analytic study with a cross sectional design. The sample of this study were HIV/AIDS sufferers who carried out ARV therapy in Manahan Surakarta Health Center amounting to 36 respondents. The data collection tools are questionnaires and literature study. Data analysis was performed using logistic regression.

\section{RESULTS}

The results of study subject's characteristics can be seen in Table 1 . Table 1 indicates that the majority of the study subjects had education level senior high school (61.1\%), with private employment (41.7\%), male 
Journal of Health Promotion and Behavior (2016), 1(1): 55-62

https://doi.org/10.26911/thejhpb.2016.01.01.08

gender (88.9\%), and 28 people obeyed ARV therapy (77 8\%).

Table 1. Study subject's characteristics based on education, gender, occupation, and adherence to ARV therapy

\begin{tabular}{lcc}
\hline Education & $\mathbf{n}$ & $\mathbf{\%}$ \\
<Senior high school & 5 & 13.9 \\
Senior high school & 22 & 61.1 \\
College & 9 & 25.0 \\
Occupation & & \\
Housewife / not working & 10 & 27.8 \\
Private & 15 & 41.7 \\
Employee & 11 & 30.6 \\
Gender & & \\
Male & 32 & 88.9 \\
Female & 4 & 11.1 \\
ARV therapy adherence & & \\
Yes & 28 & 77.8 \\
No & 8 & 22.2 \\
\hline
\end{tabular}

Table 2 shows that there was a relationship between knowledge and adherence and ARV therapy but it was statistically not significant $(\mathrm{OR}=0.80 ; \mathrm{p}=$ 0.786). This result indicates that study subject with good knowledge had a 0.80 times higher likelihood to adhere in ARV therapy than mother with poor knowledge.

Table 2. Chi square test between knowledge towards ARV and ARV therapy adherence

\begin{tabular}{|c|c|c|c|c|}
\hline \multirow[t]{2}{*}{ Knowledge } & \multicolumn{2}{|c|}{$\begin{array}{c}\text { ARV } \\
\text { therapy } \\
\text { adherence }\end{array}$} & \multirow[t]{2}{*}{ OR } & \multirow[t]{2}{*}{$\mathbf{p}$} \\
\hline & No & Yes & & \\
\hline Poor & 3 & 12 & & \\
\hline Good & 5 & 16 & 0.80 & 0.786 \\
\hline Total & 8 & 28 & & \\
\hline
\end{tabular}

Table 3 shows that there was an association between perceived severity and ARV therapy adherence and it was statistically significant $(\mathrm{OR}=9.0 ; \mathrm{p}=0.016)$. It indicates that study subject with strong perceived severity was 9.0 times more likely to adhere to ARV therapy than study subject with low perceived severity.
Table 3. Chi square test between perceived severity and ARV therapy adherence

\begin{tabular}{ccccc}
\hline \multirow{2}{*}{$\begin{array}{c}\text { Perceived } \\
\text { severity }\end{array}$} & \multicolumn{2}{c}{$\begin{array}{c}\text { ARV therapy } \\
\text { adherence }\end{array}$} & OR & p \\
\cline { 2 - 3 } & No & Yes & & \\
\hline Low & 6 & 7 & & \\
High & 2 & 21 & 9.0 & 0.016 \\
Total & 8 & 28 & & \\
\hline
\end{tabular}

Table 4 shows that there was a relationship between perceived benefit and barrier with ARV therapy adherence and it was statistically significant $(\mathrm{OR}=9.0 ; \mathrm{p}=$ o.016). It indicates that study subject with high perceived benefit and barrier was 9.0 times more likely to adhere to ARV therapy than study subject with low perceived benefit and barrier.

Table 4. Chi square test perceived benefit and barrier with ARV therapy adherence

\begin{tabular}{|c|c|c|c|c|}
\hline \multirow{2}{*}{$\begin{array}{c}\text { Perceived } \\
\text { Benefit } \\
\text { and } \\
\text { barrier }\end{array}$} & \multicolumn{2}{|c|}{$\begin{array}{l}\text { ARV therapy } \\
\text { adherence }\end{array}$} & \multirow[t]{2}{*}{ OR } & \multirow[t]{2}{*}{$\mathbf{p}$} \\
\hline & Yes & Yes & & \\
\hline High & 6 & 7 & & \\
\hline Low & 2 & 21 & 9.0 & 0.016 \\
\hline Total & 8 & 28 & & \\
\hline
\end{tabular}

Table 5 shows that there was a relationship between family support and ARV therapy adherence $(\mathrm{OR}=7.5 ; \mathrm{p}=$ 0.036). It indicates that study subjects with strong family support were 7.5 times more likely to adhere to ARV therapy than study subjects with weak family support.

Table 5. Chi square test of family support with ARV therapy adherence

\begin{tabular}{lcccc}
\hline \multirow{2}{*}{$\begin{array}{c}\text { Family } \\
\text { Support }\end{array}$} & \multicolumn{2}{c}{$\begin{array}{c}\text { ARV therapy } \\
\text { adherence }\end{array}$} & & \\
\cline { 2 - 3 } OR & No & Yes & & \\
\hline Weak & 6 & 8 & & \\
Strong & 2 & 20 & 7.5 & 0.036 \\
Total & 8 & 28 & & \\
\hline
\end{tabular}

The multivariate test results with logistic regression in Table 6 show the 
results of multiple logistic regression. There is a statistically not significant relationship of Knowledge about ARVs with adherence to ARV therapy $(\mathrm{OR}=4.03 ; 95 \% \mathrm{CI}=0.22$ to $73.32 ; \mathrm{p}=0.347)$. There was a positive relationship that was statistically significant from the perception of the severity of the disease with adherence to ARV therapy (OR $=26.70 ; 95 \% \mathrm{CI}=1.30$ to $550.51 ; \mathrm{p}=$ 0.033). There was a positive and statistically significant relationship of perceived benefits and barriers to adherence to ARV therapy (OR = 17.73; 95\% CI $=1.12$ to $279.59 ; \mathrm{p}=0.041)$. There was a statistically significant positive relationship of family support with adherence to ARV therapy ( $\mathrm{OR}=28.89$; $95 \% \mathrm{CI}=1.24$ to $647.71 ; \mathrm{p}=0.036)$.

Table 6. Multiple logistic regression analysis

\begin{tabular}{lcccc}
\hline \multirow{2}{*}{ Independent Variables } & \multirow{2}{*}{ OR } & \multicolumn{2}{c}{ 95\% CI } & \multirow{2}{*}{ p } \\
\cline { 3 - 4 } & & Lower limit & Upper limit & \\
\hline Knowledge & 4.03 & 0.22 & 73.32 & 0.347 \\
Perceived severity of the disease & 26.70 & 1.30 & 550.51 & 0.033 \\
Perceived of benefit and barrier & 17.73 & 1.12 & 279.59 & 0.041 \\
Family Support & 28.89 & 1.24 & 647.71 & 0.036 \\
N observation & 36 & & & \\
-2 log likelihood $=19.08$ & & & \\
Nagelkerke $\mathrm{R}^{2}=62.9 \%$ & & & \\
\hline
\end{tabular}

The Negelkerke $\mathrm{R}^{2}=62.9 \%$ means that the four independent variables (knowledge of HIV / AIDS, perceptions of disease severity, perceived benefits and barriers, and family support) were able to explain the adherence of ARV therapy by $62.9 \%$ and the remaining $37.1 \%$ explained by other factors outside research model. Of the four independent variables that were most associated with adherence to ARV therapy was perceived severity $(p=0.033)$.

\section{DISCUSSIONS}

\section{The relationship between know- ledge toward ARV and ARV therapy adherence}

The result of the study showed that there was a relationship between knowledge of HIV/AIDS and the compliance to ARV therapy which was statistically insignificant with the score of $(p=0.786)$, in this study, good knowledge would increase the compliance to conduct ARV therapy, while the relationship between knowledge and compliance behavior was not significant because the compliance to ARV therapy was not only influenced by knowledge about HIV/AIDS but also knowledge about the ARV itself.

The result of this study was in accordance with a study done by Suryani, Citrakesumasari and Jafar (2011) which stated that there was no effect of knowledge on behavior. Although knowledge was part of the behavior area, it did not guarantee that someone with sufficient knowledge has the same behavior.

The informational factor also played a role in the knowledge of someone who would determine how a person behave according to the information received. This approach was usually used to use public awareness of an innovation that influenced the behavior change, it usually used through mass media (Wawan and Dewi, 2010). In this study, the dissemination of ARVs in the community has not been as much as the socialization of HIV/AIDS, this 
Journal of Health Promotion and Behavior (2016), 1(1): 55-62

https://doi.org/10.26911/thejhpb.2016.01.01.08

has enabled the community and even the sufferers themselves to not fully know about ARV that have an impact on the compliance to ARV therapy.

\section{The relationship between per- ceived severity and ARV therapy adherence}

The result of the study showed that there was a relationship between perceived seriousness of the disease and the compliance to HIV/AIDS therapy which was statistically significant with the score of $(\mathrm{p}=$ o.016), high perceived seriousness of a disease which in this case was HIV/AIDS, would increase the behavior of conducting the treatment which was ARV therapy. These results supported the research of Safri, Sukartini and Ulfiana (2013) which showed that perceived susceptibility, perceived seriousness, perceived benefit and barriers and cues to action have a significant effect on the compliance to take medication for TB patients.

Rosenstock et al. (2011) stated that perceived seriousness or severity of an illness caused a person to make a treatment effort.

It can be concluded that perception or assumption about the seriousness of an illness which in this case was HIV/AIDS could make the respondents to do ARV therapy. This was because they did not want to get other infections and prolong their life.

\section{The relationship between per- ceived benefit and barrier and ARV therapy adherence}

The result of the study showed that there was a relationship between perceived benefit and barrier and the compliance to ARV therapy which was statistically significant with the score of $(p=0.016)$, high perceived benefit and barrier would increase the compliance to conduct ARV therapy. These results supported the research of Obiri- korang et al. (2013) which stated that other diseases and drug side effects negatively affected the adherence of ARV therapy while the perceptions of health, family support and regularity have a positive effect on ARV therapy.

Sirait and Sarumpaet (2012) stated that the component of the Health Belief Model (HBM) was related to the behavior of condom use in Ship Crew in belawan harbor, which was perceived seriousness $(\mathrm{PR}=1.29 ; \mathrm{p}=0.047 ;)$. This research was supported by a study done by Safri, Sukartini and Ulfiana (2013) which stated that perceived seriousness, perceived benefits and barriers have a significant effect on the compliance to take medication for $\mathrm{TB}$ patients.

Becker and Rosenstock (in Sarafino, 2006) stated that in perceived benefits, individuals assumed that she/he would get benefit in obtaining certain health services, such as getting healthier and reducing perceived risk, while perceived barriers were individuals who felt obstacles when obtaining certain health services, for example in consideration of costs, psychological consequences (for example, fear of getting older if doing a check up), physical considerations (for example, the hospital was far from the house. Sum was seen as the benefit obtained after being reduced by the barriers. Sum was the extent to which the action would provide benefit than not doing the action.

\section{The relationship between family support and ARV therapy adherence}

The result of the study showed that there was a relationship between family support and the compliance to ARV therapy on HIV/AIDS patients which was statistically significant with the score of $(p=0.026)$, strong family support to HIV/AIDS sufferers through material support, infor- 
mation, and emotions would increase the compliance in conducting ARV therapy. The result of this study was supported by a study done by Obikorang, et al (2013) which showed that perceived personal health, family support, and regularity have a positive effect on ARV therapy.

The result of this study was supported by a study done by Ubra (2012) which stated that educational level, employment, ethnicity and family support were related to the treatment compliance of ARV in HIV patients. Everyone needed help from others, the supports were in the form of sympathetic support and empathy, love, trust and appreciation. Thus someone who faced a problem felt that he/she has someone who care, want to hear all his/her complaints, sympathize and empathize with the problems he/she faced, even want to solve the problems (House, in Adicondro and Purnamasari, 20 11).

Lack of medication adherence would make PLWHA resistant to therapy with the consequence of being able to transmit resistant viruses to others. The job of the counselor was to establish the adherence support counseling and convey the basic methods of ARV drugs, the occurrence of treatment failure, and ways to avoid noncompliance (Ministry of Health, 2011). Factors associated with low adherence to antiretroviral drugs can be caused by a lack of harmony between HIV patients and health personnels, the number of pills, forgetfulness, depression, level of education, lack of patients' understanding about medicines that must be swallowed, drug toxicity, and patients were too sick to swallow the drugs (Health Department, 2008).

\section{The relationship between know- ledge toward ARV, perceived seriousness, perceived benefit and barrier, and family support with ARV therapy adherence}

The results of the study showed that the four independent variables (knowledge of HIV/AIDS, perceived seriousness of the disease, perceived benefits and barriers, and family support) the variable of perceived seriousness of the diesease was the most related variable in statistical method ( $p=0.033)$. High perceived seriousness of a disease which in this case was HIV/AIDS, would make the individuals to take ARV treatment. This was because they did not want to get serious illnesses and can extend their life expectancy. This was supported by Rosenstock et al (2011) which stated that the perceived seriousness or severity of an illness caused a person to conduct a treatment.

Health Belief Model (HBM) explained that the possibility of an individual to take a preventive action depended directly on two beliefs or health beliefs, namely the perceived threat of pain and consideration of benefit or losses, threats, seriousness, and consideration of the advantages and disadvantages of recommended behavior (Pujiyanti et al, 2010).

There was a positive relationship which was statistically significant between perceived seriousness of a disease and the compliance to ARV therapy $(\mathrm{OR}=26.70$; $95 \% \mathrm{CI}=1.30$ to $550.51 ; \mathrm{p}=0.033)$. perceived benefit and barrier with the compliance to ARV therapy $(\mathrm{OR}=17.73 ; 95 \%$ $\mathrm{CI}=1.12$ to $279.59 ; \mathrm{p}=0,041)$. Family support and the compliance to ARV therapy $(\mathrm{OR}=28.89 ; 95 \% \mathrm{CI}=1.24$ to $647.71 ; \mathrm{p}=$ o.036) For the knowledge factor, other factors needed to be involved, such as good information and socialization of services education, location services, affordable 
Journal of Health Promotion and Behavior (2016), 1(1): 55-62

https://doi.org/10.26911/thejhpb.2016.01.01.08

costs so that the clients can access and understand the importance of services for them. There were many other variables that should be explored for the success of this study such as socio-economic, sociocultural, age, and ethnicity.

\section{REFERENCES \\ $\overline{\text { Adicondro N, Purnamasari A (2011). Efika- }}$ si Diri, Dukungan Sosial Keluarga Dan SelfRegulated Learning. 8 (3). \\ Departemen Kesehatan Republik Indone- sia. (2008). Modul Pelatihan Pemce- gahan penularan HIV/AIDS dari Ibu ke Bayi (PMTCT). Jakarta : Departe- men Kesehatan Republik Indonesia}

Kementerian Kesehatan Republik Indoesia. (2011). Pedoman Nasional Tatalaksana Klinis Infeksi HIV dan Terapi Antiretroviral pada orang Dewasa dan Remaja. Jakarta: Direktorat Jenderal Pengendalian Penyakit dan Penyehatan Lingkungan Kementerian Kesehatan RI 2011.

KPAD Solo. (2014). Kobappeda. Surakarta.go.id/content/komisi - penang gulangan-aids-daerah-kpad-2013

Laksana ASD, Lestari DWD (2010). FaktorFaktor Risiko Penularan HIV/ AIDS Pada Laki-Laki Dengan Orientasi Seks Heteroseksual Dan Homoseksual Di Purwokerto. Mandala of Health. 4(2): 113-123.

Obirikorang C, Selleh PK, Abledu JK. Fofie $\mathrm{CU}$ (2013). Predictors of Adherence to Antiretroviral Therapy among HIV/AIDS Patientsin the Upper West Region of Ghana. Research Article. 2 (1): 1-8.

Rachmawati S. (2013). Kualitas Hidup Orang Dengan HIV / AIDS Yang Mengikuti Terapi Antiretroviral. Jurnal Sains Dan Praktik Psikologi. 1 (1): $48-62$
Rosenstock IM, Strecher VJ, Becker MH. (1988). Social Learning Theory and The Health Belief Model, Health Education Behavior. Vol. 15.

Safri FM, Sukartini T dan Ulfiana E. (2013). Analisis Faktor Yang Berhubungan Dengan Kepatuhan Minum Obat Pasien Tb Paru Berdasarkan Health Belief Model di Wilayah Kerja Puskesmas Umbulsari, Kabupaten Jember. Jurnal Universitas Airlangga, pp :1-10.

Sarafino EP. (2006). Health Psychology: Biopsychosocial Interaction. USA: John Willey and Sons

Sirait LM and Sarumpaet S. (2012). Hubungan Komponen Health Belief Model (HBM) Dengan Penggunaan Kondom Pada Anak Buah Kapal (ABK) Di Pelabuhan Belawan.Jurnal Precure. 1(1): 43-49.

Suryani EP, Citrakesumasari, Jafar N (2011). Hubungan Perilaku Gizi seimbang Dengan status gizi pada Mahasiswa Angkatan 2010 Fakultas kesehatan masyarakat Universitas hasanuddin. Makasar: Journal of The Indonesian Nutrition Association, Volume XXI, PERSAGI.

Ubra RR. (2012). Faktor-Faktor Yang Berhubungan Dengan Kepatuhan Pengobatan Minum ARV Pada Pasien HIV di Kabupaten Mimika Provinisi Papua Tahun 2012. Tesis. Depok: Program Pascasarjana Fakultas Kesehatan Masyarakat Universitas Indonesia.

Wawan A dan Dewi M. (2010). Teori dan Pengukuran Pengetahuan, Sikap dan Perilaku Manusia. Yogyakarta: Nuha Medika.

WHO (2015). HIV/AIDS, diakses dari http://www.who.int, tanggal 5 Februari 2015 . 
Yuniar Y, Handayani RS, Aryastami NK. (2013). Faktor-Faktor Pendukung Kepatuhan Orang Dengan HIV AIDS (ODHA) Dalam Minum Obat Anti- retroviral Di Kota Bandung Dan Cimahi. Buletin Penelitian Kesehatan. 41(2): 72-83 